\title{
A Comparison of Organic Cement Made from Recycled Waste Material and Portland Cement
}

\author{
Muhammad Syarif \\ Department of Architecture \\ Muhammadiyah University of Makassar \\ Makassar, Indonesia
}

\author{
M. Wihardi Tjaronge \\ Department of Civil Engineering \\ Hasanuddin University \\ Makassar, Indonesia
}

\begin{abstract}
Organic cement is an environmentally friendly alternative to Portland cement which is acquired by recycled organic waste and Mediterranean soil. Waste management is a global problem. The physical characteristic test results of the organic cement show that the weight test of fresh organic concrete is $2081 \mathrm{~kg} / \mathrm{m}^{3}$ and the dry weight of concrete is $2032 \mathrm{~kg} / \mathrm{m}^{3}$ which are smaller than Portland cement concrete's which are $2525 \mathrm{~kg} / \mathrm{m}^{3}$ and $2405 \mathrm{~kg} / \mathrm{m}^{3}$ respectively. The fineness of alternative cement grains that passed the 200 mesh sieve is $56 \%$, which is more than Portland cement's which is $52 \%$. The solid weight of alternative cement is $1200 \mathrm{~kg} / \mathrm{m}^{3}$ whereas the solid weight of Portland cement is $1250 \mathrm{~kg} / \mathrm{m}^{3}$.
\end{abstract}

Keywords-bleeding; finenes; Mediterranean soil; organic cement; organic waste

\section{INTRODUCTION}

This study aims to develop previous experimental research which can be found in [1]. Organic cement is the latest alternative to Portland cement and is made through organic waste recycling and Mediterranean soil substitution of Portland cement [2]. The necessity of building materials needs to be addressed by researching the utilization of recycling waste to obtain alternative building materials [3]. Gradually, high waste volume has a negative impact on the environment, so handling of waste is necessary. Urban waste management in Indonesia is a real problem as population growth has an impact on the amount of produced waste and the occurrence of degradation problems that have the potential to cause social conflict to the communities $[4,5]$. The high growth of waste volume coincides with high population growth rate. Therefore, the waste management problem can be considered as a global problem.

In [6], it was shown that handling of organic waste through the combustion process with the furnace at $700{ }^{\circ} \mathrm{C}$ will provide materials such as: $69.7 \% \mathrm{CaCo}_{3}, 12.1 \% \mathrm{KCl}, 3 \% \mathrm{SiO}_{2}, 8.1 \%$ $\mathrm{Fe}$ and $3 \% \mathrm{Al}_{2}$, while shellfish ash contains $100 \% \mathrm{CaCo}_{3}[6]$. Along with economic growth, per capita garbage production will continue to increase. It is predicted to reach $1.2 \mathrm{~kg} / \mathrm{person} /$ day for urban areas and $0.55 \mathrm{~kg} / \mathrm{person} /$ day for rural areas by 2030. In Indonesia, organic waste is a major component of waste. The proportion of organic waste ranges between 34 and $70 \%$ which is $20-30 \%$ higher than most countries in Europe [7].
Mediterranean soil is a soil formed from weathering of sedimentary rock and limestone. This type of soil contains a considerable amount of carbonate and compounds of iron, water, aluminum, along with some organic materials [8]. Additional mineral components are called reactive supplemental minerals and contribute to the hydration process. Other additions include natural pozzolans and microsilica/silica fume [9]. The highest tensile strength in 14-day-old concrete with the addition of $5 \%$ bagasse ash is $6.221 \mathrm{MPa}$ representing an increase of $2.45 \%$ [10]. The increase in cement growth is still influenced by the high level of private sector development and the high demand for housing [11]. A cement that contains mineral elements as a substitute for Portland cement is known as composite cement, mixed cement or alternative cement. The additional mineral is reactive and contributes to the hydration process. The use of saturated fly ash is one way to reduce high exposure in the process of hydration to the density of cement in concrete $[12,13]$. The use of alternative sources for the manufacture of cement developed in Japan produced ecocement made from municipal waste ash through incineration as a substitute for some of the main raw materials containing 50\% of cement raw materials such as mud waste [14]. To create an Eco-Semen CSA Clinker, the appropriate starting raw material needs to be burned at a maximum temperature of $1200-1300^{\circ} \mathrm{C}$. Reuse of waste materials in the form of phosphogypsum will reduce the temperature and duration of the combustion process. Large-scale eco-cement making can be done in conventional rotary kilns used for Portland cement and producing chemical cement mineralization [15].

\section{RESEARCH METHODOLOGY}

Characteristic testing was performed on the organic cement. The tests included bleeding test, air content test, fineness test, normal consistency test, and unit weight test. The references to the test method come from the American Society for Testing and Materials (ASTM) which include: ASTM C 188-95 for granular fineness/density tests [16], ASTM C 232-99 for fresh concrete bleeding test [17], and ASTM C 231-03 for air content of freshly mixed concrete [18]. They are normative references that are considered very relevant in the process of testing the physical properties of cement. 


\section{RESULTS AND DISCUSSION}

\section{A. Air Content}

The obtained results of air content test can be seen in Table I. In this study, the air content value of fresh concrete was calculated by using an organic cement test sample and the results were compared with the ones of fresh concrete of Portland cement. Figure 1 shows the measuring percentage process of the air content value of fresh concrete in both organic cement concrete and Portland cement concrete samples.

(a)

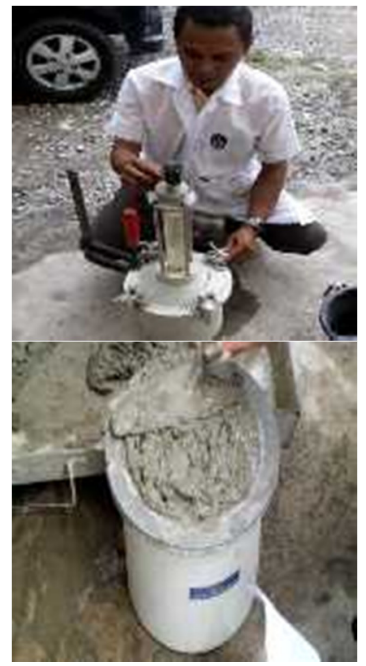

Fig. 1. Measuring process of air content.

TABLE I. AIR CONTENT RESULTS

\begin{tabular}{|c|c|c|}
\hline & $\begin{array}{c}\text { Organic cement } \\
\text { concrete }\end{array}$ & $\begin{array}{c}\text { Portland cement } \\
\text { concrete }\end{array}$ \\
\hline Test concrete volume $\left.\mathbf{( m}^{\mathbf{3}}\right)$ & 0.0016 & 0.0016 \\
\hline Correction factor reading & $1 \%$ & $1 \%$ \\
\hline Reading result & $3.2 \%$ & $2.9 \%$ \\
\hline Air content of reading result & $2.2 \%$ & $1.9 \%$ \\
\hline Air content for $\mathbf{1 ~ m}^{\mathbf{3}}$ (prediction) & $13.75 \%$ & $11.88 \%$ \\
\hline
\end{tabular}

\section{B. Bleeding}

The amount of water bleeding is shown in Table II. A organic cement concrete cylinder with a weight of $3.33 \mathrm{~kg}$ has a water-bleeding value of $0.04 \mathrm{ml} / \mathrm{cm}^{2}$, so the prediction of water-bleeding for $1 \mathrm{~m}^{3}$ of organic cement concrete is $23.88 \mathrm{ml} / \mathrm{cm}^{3}$. Meanwhile, for concrete that utilizes Portland cement the weight of the same cylinder was $3.36 \mathrm{~kg}$ with a water-bleeding value of $0.05 \mathrm{ml} / \mathrm{cm}^{2}$ and the prediction for $1 \mathrm{~m}^{3}$ was $31.83 \mathrm{ml} / \mathrm{cm}^{3}$. Testing of water-bleeding volume of cylinder concrete is calculated by [17]:

$$
\text { Bleeding }=V / A\left(\mathrm{ml} / \mathrm{cm}^{2}\right)
$$

where $V$ is the water-bleeding volume of the test specimen (ml) and $A$ is the surface area of the test specimen $\left(\mathrm{cm}^{2}\right)$.

Figure 2(a) shows the process of taking and measuring water bleeding. Figure 2(b) shows a graph of the amount of water bleeding to the cylinder concrete weight between an organic cement cylinder concrete with a Portland cement cylinder concrete.

TABLE II. BLEEDING TEST RESULTS

\begin{tabular}{|c|c|c|}
\hline & $\begin{array}{c}\text { Organic } \\
\text { cement }\end{array}$ & $\begin{array}{c}\text { Portland } \\
\text { cement }\end{array}$ \\
\hline Test specimen weight $(\mathbf{k g})$ & 3.33 & 3.36 \\
\hline Cylinder volume $\left(\mathbf{m}^{\mathbf{3}}\right)$ & 0.0016 & 0.0016 \\
\hline Test specimen area $\left(\mathbf{c m}^{\mathbf{2}}\right)$ & 78.53 & 78.53 \\
\hline Test specimen bleeding $\boldsymbol{V}(\mathbf{m l})$ & 3 & 4 \\
\hline $\boldsymbol{V} / \boldsymbol{A}\left(\mathbf{m l} / \mathbf{c m}^{\mathbf{2}}\right)$ & 0.04 & 0.05 \\
\hline $\begin{array}{c}\text { Prediction of bleeding in } \mathbf{1 m}^{\mathbf{3}} \\
\text { concrete }\left(\mathbf{m l} / \mathbf{c m}^{\mathbf{3}}\right)\end{array}$ & 23.88 & 31.83 \\
\hline
\end{tabular}

(a)
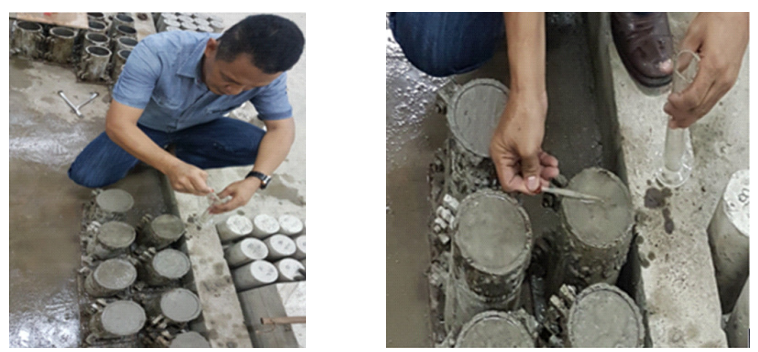

(b)

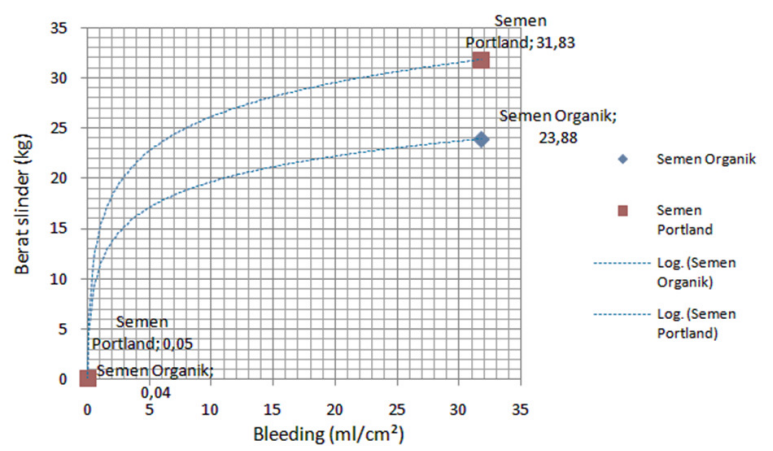

Fig. 2. (a) Bleeding measurement process, (b) amount of water bleeding graph.

\section{Fineness and Density}

The more fine the cement, the wider the surface of the grains, and the compacting with water will be faster and will require larger amount of water. The value of material fineness for organic cement which passes the 200 mesh sieve is $56 \%$ with solid weight of $1200 \mathrm{~kg} / \mathrm{m}^{3}$, while for Portland cement, it is $52 \%$ with solid weight of $1250 \mathrm{~kg} / \mathrm{m}^{3}$. Fineness and density tests in this research refer to the formulation in [16]. Figure 3 shows the fineness of the organic cement and Portland cement concretes whereas Figure 4 shows the process of the fineness test. The calculation formula of fineness percentage is:

$$
\frac{D}{B} \times 100 \%=\frac{C-A}{B} \times 100 \%
$$

where $D$ is the weight restrained on each sieve, $B$ is the sample weight. The density test result of organic cement is $3.05 \mathrm{gr} / \mathrm{ml}$ while for Portland cement is $3.15 \mathrm{gr} / \mathrm{ml}$. This density greatly affects the proportion of the cement use in the mixture. Figure 5 shows the density test process of organic and Portland cements. 


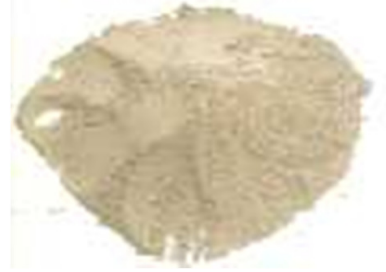

(a)

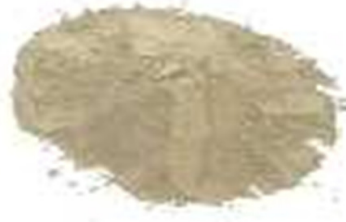

(b)
Fig. 3. (a) Organic cement with density of $3.05 \mathrm{gr} / \mathrm{ml}$, (b) Portland cement with density of $3.15 \mathrm{gr} / \mathrm{ml}$.
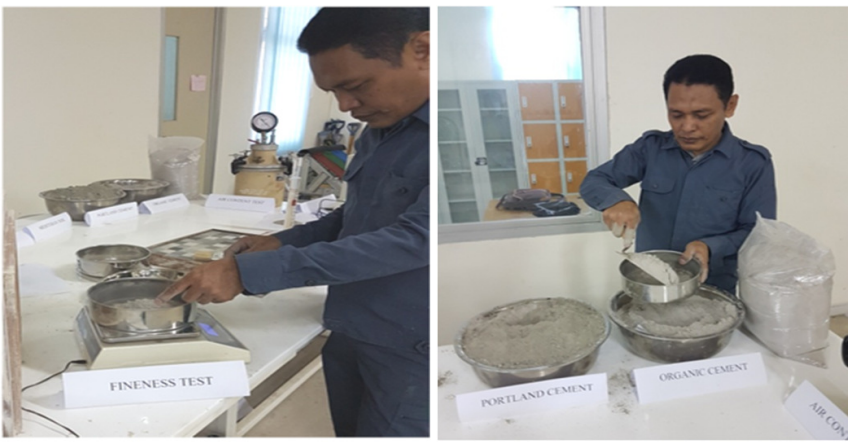

Fig. 4. Fineness test process.

The density calculation formula used in this research is :

$$
\text { Density }=\frac{\text { cement weight }}{\left(V_{2}-V_{1}\right)} \times d
$$

where $V_{1}$ is the first reading of bottle scale, $V_{2}$ the second reading, and $d$ denoted the content weight of distilled water which is $1 \mathrm{gr} / \mathrm{cm}^{3}$.
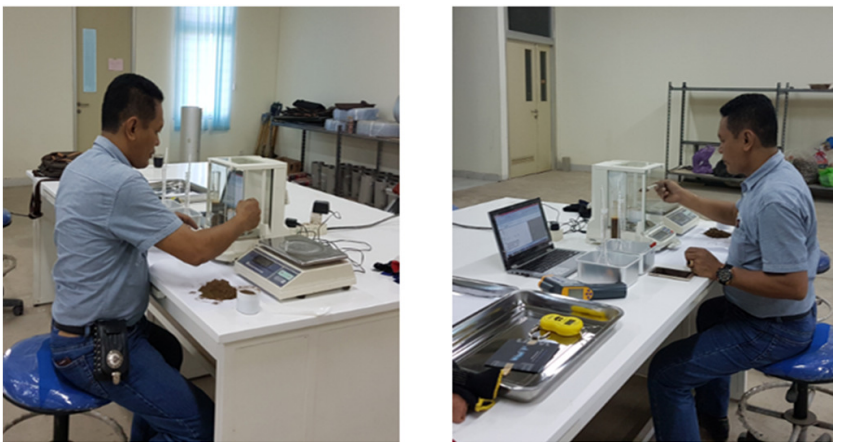

Fig. 5. Density test of organic cement.

\section{Unit Weight}

The unit weight of fresh concrete using organic cement is $2081 \mathrm{~kg} / \mathrm{m}^{3}$ with its dry weight being $2032 \mathrm{~kg} / \mathrm{m}^{3}$, while, for Portland cement, the unit weight of fresh concrete is $2525 \mathrm{~kg} / \mathrm{m}^{3}$ with $2405 \mathrm{~kg} / \mathrm{m}^{3}$ dry weight. The unit weight test results are shown in Table III. The weight of a concrete cylinder using organic cement and of the cylinder using Portland cement are shown in Figure 6(a) whereas in Figure $6 \mathrm{~B}$ the concrete cylinders' condition at 28 days can be seen. (a)

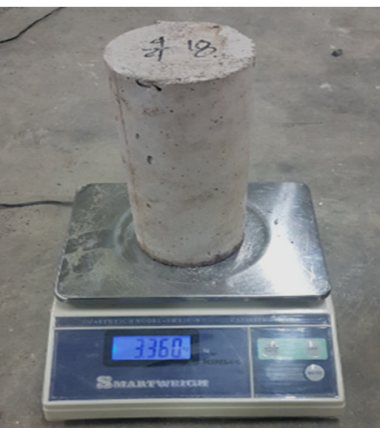

(b)
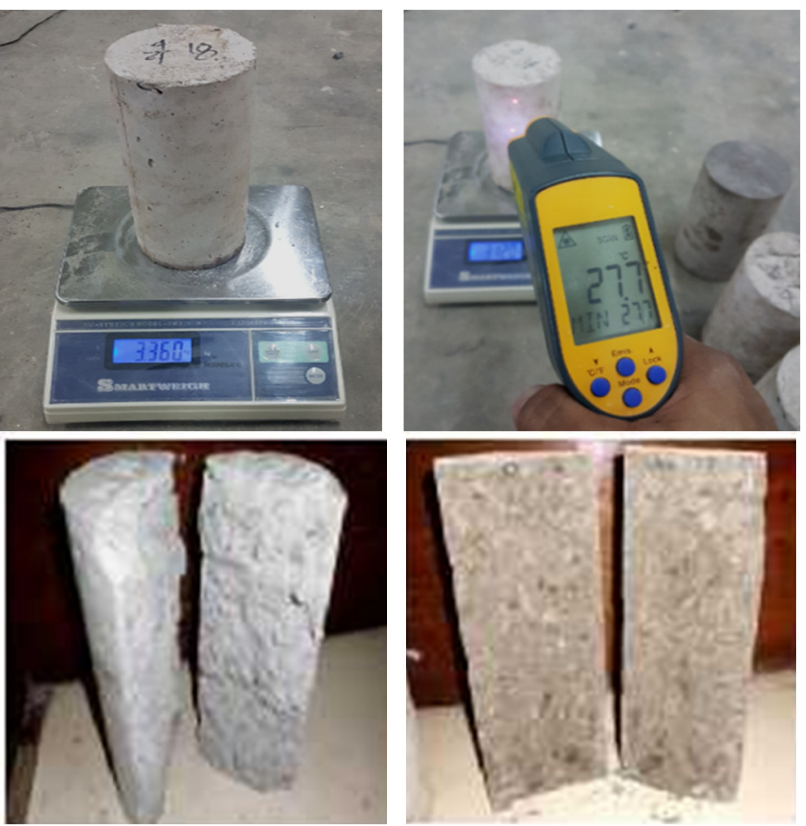

Fig. 6. Weight and temperature measurement of (a) organic cement concrete, (b) Portland cement concrete.

TABLE III. UNIT WEIGHT TEST RESULTS

\begin{tabular}{|c|c|c|}
\hline & Organic cement & Portland cement \\
\hline Cylinder mold weight (kg) & 6.20 & 6.20 \\
\hline Test specimen weight (kg) & $9.53-6.20=3.33$ & $10.24-6.20=4.04$ \\
\hline Cylinder volume (m $\left.\mathbf{m}^{\mathbf{3}}\right)$ & 0.0016 & 0.0016 \\
\hline $\begin{array}{c}\text { Fresh concrete weight } \\
\left(\mathbf{k g} / \mathbf{m}^{\mathbf{3}}\right)\end{array}$ & $3.33 / 0.0016=2081$ & $4.04 / 0.0016=2525$ \\
\hline $\begin{array}{c}\text { Dry concrete weight at } \mathbf{2 8} \\
\text { days }\left(\mathbf{k g} / \mathbf{m}^{\mathbf{3}}\right)\end{array}$ & $3.25 / 0.0016=2031$ & $3.85 / 0.0016=2406$ \\
\hline
\end{tabular}

\section{CONCLUSIONS}

In this paper, the physical properties of organic cement were tested in the form of granular fineness/density, unit weight of dry and fresh concrete, and bleeding and the results were compared with the ones regarding Portland cement. Organic cement has been found to indicate similarities in physical properties with Portland cement, whereas organic cement has also been able to bind and contain amorphous pozzolanic materials. To achieve improved binding and better resilience, further research is required as a process of seeking the feasibility of organic cement into an alternative of Portland cement.

\section{REFERENCES}

[1] M. Syarif, V. Sampebulu', M. Wihardi Tjaronge, and Nasruddin, "Characteristic of compressive and tensile strength using the organic cement compare with portland cement," Case Studies in Construction Materials, vol. 9, Dec. 2018, Art. no. e00172, https://doi.org/10.1016/ j.cscm.2018.e00172.

[2] M. Syarif, "A Study of Cement Made From Recycled Gerbage Materials Compared With Portland Cement," presented at the Third International Cenference on Sustainable Infrastructure and Built Environment (SIBE2017), Bandung, Indonesia, Sep. 2017.

[3] M. Syarif, "Karakteristik Sampah Organik dan Tanah Mediteran Menjadi Semen Organik," presented at the Konferensi Nasional Teknik Sipil 11 (KONTEKS-11), Jakarta, Indonesia, Oct. 2017. 
[4] R. P. Mahyudin, "Kajian Permasalahan Pengelolaan Sampah Dan Dampak Lingkungan Di TPA (Tempat Pemrosesan Akhir)," Jukung (Jurnal Teknik Lingkungan), vol. 3, no. 1, pp. 66-74, Apr. 2017, https://doi.org/10.20527/ jukung.v3i1.3201.

[5] I. W. Widiarti, "Pengelolaan Sampah Berbasis Zero Waste Skala Rumah Tangga Secara Mandiri," Jurnal Sains \& Teknologi Lingkungan, vol. 4, no. 2, pp. 101-113, Jun. 2012, https://doi.org/10.20885/jstl.vol4.iss2.art4.

[6] F. A. Syafnijal and D. Sawitri, "Studi Eksperimental Pembuatan Ekosemen dari Abu Sampah dan Cangkang Kerang sebagai Bahan Alternatif Pengganti Semen," Jurnal Teknik ITS, vol. 2, no. 2, pp. D162-D165, Aug. 2013, https://doi.org/10.12962/j23373539.v2i2.4287.

[7] A. S. Alisjahbana et al., "Indonesia Climate Change Sectoral Roadmape (ICCSR)," Republic of Indonesia, Indonesia, Synthesis Report, Dec. 2009.

[8] A. Maulana, Fungsi Tanah Mediteran Bagi Kehidupan. 2016.

[9] W. B. Nicholas, Understanding Cement, Low Concrete Strenght, Ten Potential Cement-Related Causes. UK: Copyright WHD Microanalysis Consultan Ltd, 2014.

[10] G. P. Rompas, J. D. Pangouw, R. Pandaleke, and J. B. Mangare, "Pengaruh Pemanfaatan Abu Ampas Tebu Sebagai Subtitusi Parsial Semen Dalam Campuran Beton Ditinjau Terhadap Kuat Tarik Lentur Dan Modulus Elastisitas," Jurnal Sipil Statik, vol. 1, no. 2, pp. 82-89, Jan. 2013.

[11] R. R. Nur, F. D. Hartanti, and J. P. Sutikno, "Studi Awal Desain Pabrik Semen Portland dengan Waste Paper Sludge Ash sebagai Bahan Baku Alternatif," Jurnal Teknik ITS, vol. 4, no. 2, pp. F164-F168, 2015, https://doi.org/10.12962/j23373539.v4i2.9868.

[12] V. Sampebulu, "Influence of High Temperatures on the Workability of Fresh Ready-Mixed Concrete," Journal of Engineering and Technological Sciences, vol. 44, no. 1, pp. 21-32, 2012, https://doi.org/10.5614/itbj.eng. sci.2012.44.1.2.

[13] V. Sampebulu', "Increase on Strengths of Hot Weather Concrete by SelfCuring of Wet Porous Aggregate," Civil Engineering Dimension, vol. 14, no. 2, pp. 92-99, Sep. 2012, https://doi.org/10.9744/ced.14.2.92-99.

[14] S. Hanehara, "Eco-Cement and Eco-Concrete Environmentally Compatible Cement and Concrete Technology," in JCI/KCI International Joint Seminar, Kyonju, South Korea, Jan. 2001, vol. 1.

[15] N. Ukrainczyk, N. Mihelj, and J. Sipusic, "Calcium Sulfoaluminate EcoCement from Industrial Waste," Chemical and Biochemical Engineering Quarterly, vol. 26, no. 1, pp. 83-93, Oct. 2011.

[16] C01 Committee, "Test Method for Density of Hydraulic Cement," ASTM International. https://doi.org/10.1520/C0188-95.

[17] C09 Committee, "Test Methods for Bleeding of Concrete," ASTM International. https://doi.org/10.1520/C0232-99.

[18] C09 Committee, "Test Method for Air Content of Freshly Mixed Concrete by the Pressure Method," ASTM International. https://doi.org/10.1520/ C0231_C0231M-17A. 